\title{
Adequacy of Indemnity Afforded by Performance Bonds Used in State Sector Construction Projects
}

\author{
Dolage and Suthesan
}

Abstract: In an effort to ease off the financial burden on contractors, a government policy was enacted on first November 1997, to reduce the existing ten percent penal sum of the performance bond to five percent. There was no overall justification for this decision. The primary aim of this study is to explore the adequacy of indemnity afforded by the penal sum of five percent, for the performance bond used in construction contracts. The sample of the study has been confined to 25 state sector building projects. These projects were either completed with the same contractor with a time extension or with a new contractor after terminating the former. The main contribution of the study is the construction of several confidence intervals for the population mean of 'total loss to the client as a percentage of the contract sum'. The study reveals a more pragmatic and compromising penal sum of seven and half percent when a conducive environment prevails to procure performance bonds. Still contractors do not have cheaper and easier ways of obtaining performance bonds. Further, performance bonds are seldom called on. Hence, the study recommends that the prevailing five percent penal sum remain the same. The study aiso has highlighted the problems the contractors encounter in procuring performance bonds from bond providers (sureties) such as banks, insurance companies and the Construction Guarantee Fund.

Keywords: Performance bonds, Construction industry, Construction guarantees

\section{Introduction}

Clients in the construction industry are becoming more and more risk averse. Most of them are determined to eliminate as much uncertainty as possible from every construction project. One way to achieve this is by making it mandatory to all the contractors to submit performance bonds. Performance bond is a guarantee given by a bank or any other agency (surety), acceptable to the client (obligee), on behalf of the contractor (principal) to the client. This is done in writing, as per the standard form issued with the tender form of a construction project. The guarantee ensures that the contractor will complete the project as per the contract agreement. It constitutes an undertaking by the bond provider to make a payment to the client in circumstances where the contractor has defaulted under the contract. The amount for which a bond would be issued is the 'penal sum' or the 'penalty amount' of the bond (Kilcullen, 1996).

In Sri Lanka, bond providers are state and private sector banks, some insurance companies and the Construction Guarantee Fund (CGF). In the current recessionary economic climate, on one hand the contractors find that the clients' demand for performance bonds has increased. Clients' interests in particular clauses therein have also increased. This is so even with the contracts that are entered into with the private clients. On the other hand, owing to the credit crunch, they face the ever increasing stringent requirements from the bond providers. The greater the penal sum of the performance bond, the lower will be the propensity to receive unrealistically low tenders from less reputable contractors. This situation would increase the chance of completing the projects in time. However, according to Construction Guarantee (2008), this is not a situation to be feared by most contractors. It says being able to obtain a bond in a recessionary economic climate should be seen as reflecting well on one's organisation.

When the penal sum is more than its affordable value, it can keep away viable and conscientious contractors. Further, the higher the penal sum the greater will be the bidder's costs of procuring the performance bonds. The prospective bidder will eventually add such

Eng. D.A.R.Dolage, CEng, FIE(Sri Lanka), BSc Eng. (Moratutva), MSc (Reading), MA (Colombo), MBA (SIP), Sentor Lecturer, Department of Civil Enginecring, The Open University of Sri Lanka

Eng. N. Suthcsan, CEng, MIE(Sri Lanka), BSc Eng. (Peradeniya), MTech (OUSL), Project Director, National Water Supply and Drainage Board 
costs to the BOQ of the tender document in an effort to recover these costs from the contract. Therefore, the objectives of this study are:

(1) to examine the issues commonly found regarding obtaining performance bonds

(2) to find an optimum penal sum for the performance bond (which is a mandatory requirement that the successful bidder has to meet) in order for the award of the construction contract.

This paper is organised as follows: Section 2 deals with the literature review on issues related to performance bonds; Section 3 illustrates the methodology of the research; Section 4 provides the results and discussion; Section 5 presents the conclusion and recommendation.

\section{Literature Review}

In the construction industry, a performance bond is a construction guarantee whereby one party (the guarantor) undertakes to pay damages to a second party (the employer) arising from breach of contract by a third party (the contractor), Construction Guarantee (2008). Performance bond is a commonly used instrument in construction contracts in order to reduce the financial risk to the client in the event the contractor fails to fulfil his contractual obligations. It is observed that most of the literature on performance bonds, deal with the issues arising from claims being made on the performance bond (Dingman 2000; Ndekugri 1999; Bennet 1994). These studies constitute strands of literature on aspects such as the importance of conforming to the notice requirements of performance bonds, explicit stating of beneficiaries and accounting to the principal when a call is made on the performance bond

Engineering News Record (2004) in a study on 'Delayed firm can not collect on project performance bond' conducted in the US, revealed an Appeals Court decision which states that construction contracts may include other prime contractors as third party beneficiaries. However, such intent (to benefit third parties) must be evidenced in the language of the contracts. In a recently decided court case (Spiersbridge Property
Developments Limited - $\mathrm{v}$ - Muir Construction Limited on 4/2/2008) the verdict given became sensational which is shown below:

"Where a demand has been made on a performance bond in an amount which is ultimately found to exceed the sum due to the party making the demand, that party is obliged to account for that excess to the opposite contracting partyin the UK on the performance bond"

Contract Journal.com., 2008).

Rossetti and Mckeeman (2007) in a study conducted in the US showed the significance of the compatibility of terms in a contract and a performance bond.

The study shows that in construction contracts used in US and UK, conditional bonds are more prevalent than 'on demand bonds'. 'On demand' bonds are rarely used in the UK construction industry, but they are a standard requirement in many international contracts. A 'conditional bond' is common within the UK construction industry. The payment is usually conditional upon the employer who makes the call justifying the amount of loss, which he has suffered. In practice, therefore, a 'conditional bond' may require litigation before any payment can be obtained. By contrast, in Sri Lanka, almost all the performance bonds used in construction contracts belong to the category of 'on demand'. Hence, the performance bonds issued in Sri Lanka are irrevocable and payment must be made even if the contractor protests. Ndekugri (1999) in a study identified the issues most commonly in dispute and the legal principles governing their resolution in connection with performance bonds and guarantees.

If the contractor fails to honour the obligations stipulated in the bond, both the contractor and the surety are liable on the bond. In the US and the UK, the obligation in the performance bond is that the principal will complete the project to the satisfaction of the client. If the principal fails to honour the obligation stated in the bond, both the principal and the surety are liable on the bond, and their liability is joint and several. As a result, the penal sum should be adequate to recover all losses incurred in completing the project. The penal sum associated with the performance bond varies across different parts of the world. In the UK construction industry, the penal sum of the bond is usually expressed as a percentage of the contract price, usually 
between five and twenty percent of the contract values with ten percent by far the most common figure (Donohue and Thomas, 1996). In Europe, the penal sum of the performance bond submitted for construction contracts varies and is in the region of 25-30 percent of the contract value. In the US - 100 percent, in Canada- 50 percent, and in Sri Lanka until $01^{\text {st }}$ November 1997 it was ten percent, but thereafter it was revised and brought down to five percent. Hence, evidently, no research study has been conducted in any country to work out an optimum value for the penal sum that can cater to the aspirations of all the three parties; the client, the contractor and the bond provider.

\section{Research Methodology}

The preliminary interviews conducted revealed that there are two types of projects that should be included in the sampling. They are namely, the projects in which the contracts were terminated and fresh tenders were called to complete the balance work (5 cases) and the projects that were not completed on time but the contractors were granted time extensions to complete the project (20 cases). A questionnaire was developed to collate information required for two purposes:

1) to assess the overall loss incurred to the client owing to the delay caused by the contractor, in the projects where the same contractor completed the project.

2) to compute the overall loss to the client in order to complete the project with a new contractor after terminating the defaulting contractor.

As the response rate for postal questionnaires is known to be poor, an interview based questionnaire survey was adopted for data gathering. The study was narrowed down in two ways; only state sector projects were considered, projects that came up in Trincomalee, Batticalo and Ampara districts were considered. A random sample of 25 projects which met the above requirements was selected from the Buildings Department (9 Nos), National Water Supply and Drainage Board (6 Nos) and Ministry of Education (10 Nos).

One of the researchers visited the above mentioned organisations, conducted the surveys and elicited information from engineers, architects and quantity surveyors who had been associated with the contract administration of these projects. The researcher took it upon himself to conduct the interview, rather than employing paid interviewers. This enabled maintaining uniformity in eliciting information from the 25 projects. In the process, the researcher made sure to engage only the engineers who had been involved with the contract administration. Further, the purpose of the study and the type of information requested in the questionnaire were clearly explained to the responsible engineers. The questionnaires were dispatched to them, a week prior to the interview. The researcher visited the respective government institutions and discussed the observations made with the engineers of the respective projects. They also verified the data obtained at the interviews and checked it against the information recorded in the project files. Further, this data were cross checked with the data from the contractors. The total loss to the client due to the delay in the project and awarding to a new contractor was computed with the use of data obtained from the questionnaires, in the following manner:

Computation of total loss to the client when the contract is terminated and a new contractor appointed on account of the failure of previous contractor to fulfil contractual obligations

With regard to the projects where the contracts were terminated and fresh tenders called to complete the balance work, the total financial implication constituted following elements of costs:

1. The cost incurred owing to the idling of all categories of staff at the site and the head office.

2. The cost incurred in the preparation of tender documents for the purpose of recalling the tenders. The information required was obtained from the respective head offices. In this regard factors such as the staff involved, their monthly salary and the time taken to complete the job were considered.

3. The costs incurred in publishing press notices regarding the second tender and the costs incurred in the tender evaluation.

4. The payments made to the contractor over and above the total value of work done by the contractor, by way of advanced payment 
and interim payments. The interest loss for the overpayment is considered too.

5. The opportunity cost of the funds that has been committed to the unutilised and incomplete project. This is computed as the interest loss for the funds that has been invested in the project at the time the contract is terminated, for the period from the date of the termination of the contract until work resumes with the new contractor.

Then total loss to the client due to the delay and having to appoint a new contractor was computed as the summation of the five elements of costs identified above

Computation of total loss to the client when the contractor is granted an extension of time on account of his failure to fulfil contractual obligations

With regard to the projects which were not completed on time but completed with the time extensions facilitated, the total financial constituted following elements of costs:

1. The cost incurred owing to the idling of all categories of staff at the site and the head office

2. The interest loss for the difference between the value of work done at the actual completion time and the value of work done at the scheduled completion time.

Then total loss to the client due to the delay was computed as the summation of the two elements of costs identified above.

\section{Results}

The total loss incurred in the two types of projects considered in the study was computed as explained in Section 3. Table 1 depicts contract sum, penal sum, five percent of the contract sum, total loss and the total loss as a percentage of the contract sum

The following observations were made regarding the results:

1) As per the results, it is noticed that in eight projects the penal sum of the performance bond is as low as two and half percent of the contract sum.
2) The average of 'total loss to the client as a percentage of the contract sum' when all 25 projects are considered is 9.32 percent.

3) The average of 'total loss to the client as a percentage of the contract sum' when the five projects (21 to 25 ) for which the contract was terminated and a new contractor appointed is 7.3.

4) The average of 'total loss to the client as a percentage of the contract sum' when the 20 (1-20) projects for which the contractor was granted an extension of time is 9.84 .

5) The standard deviation of the total loss to the client as a percentage of the contract sum' is 7.241.

6) The responses received from the contractors at the interviews regarding the ability to procure performance bond, revealed the following:

a) The commercial banks which perceive construction as a high risk activity provide guarantees only against large cash margins or against collaterals, usually in the form of immovable properties such as lands, buildings, etc. Frequently, the requisite for collateral ranges from 10 percent to 100 percent of the penal sum. Nevertheless, with less established contractors and with high risk projects this could be as high as 150 percent. The commissions charged by banks usually range from two to three percent.

b) The commissions charged by the insurance companies are higher than that charged by banks. However, unlike in the banks there is no requirement to provide collateral in this regard.

c) Alternatively, it is possible to obtain performance bonds from the CGF which is managed by a Trust. The CGF was established by Act of Parliament in 1998 with a view to overcome the constraints in undertaking construction contracts. There is a list of requirements, however, that a prospective contractor has to fulfil before being eligible to apply for a guarantee. The CGF neither require prospective contractors to keep large cash margins nor does it demand for unreasonable collaterals from 


\begin{tabular}{|c|c|c|c|c|c|c|}
\hline & Building Project & $\begin{array}{l}\text { Contract } \\
\text { Sum }\end{array}$ & $\begin{array}{l}\text { Penal } \\
\text { sum }\end{array}$ & $\begin{array}{l}\text { Five } \\
\text { percent } \\
\text { contract } \\
\text { sum }\end{array}$ & Total loss & $\begin{array}{l}\text { Total loss } \\
\text { as a } \\
\text { percentage }\end{array}$ \\
\hline 1 & $\begin{array}{l}\text { Construction of three storied building at } \\
\text { Methodist Central College, Batticaloa }\end{array}$ & $5,034,223$ & 125,800 & 251,711 & 370,382 & 7.36 \\
\hline 2 & $\begin{array}{l}\text { Construction of Teachers Training Center at } \\
\text { As-Shiraj M.V., Akkarapattu }\end{array}$ & $3,450,000$ & 141,085 & 141,085 & 52,223 & 1.51 \\
\hline 3 & $\begin{array}{l}\text { Construction of three storied building with } \\
\text { assembly hall and } 10 \text { Nos. of Class Rooms at } \\
\text { Al-Thariq MV, Trincomalee }\end{array}$ & $4,746,973$ & 118,674 & 237,348 & $1,002,841$ & 21.13 \\
\hline 4 & $\begin{array}{l}\text { Construction of Teachers Center at Jaffna } \\
\text { Hindu Ladies College }\end{array}$ & $3,375,000$ & 137,853 & 137,853 & 35,589 & 1.05 \\
\hline 5 & $\begin{array}{l}\text { Repairs and Improvement to Playground at } \\
\text { Kattankudy MMV, Batticaloa }\end{array}$ & $3,269,350$ & 81,700 & 163,467 & 449,880 & 13.76 \\
\hline 6 & $\begin{array}{l}\text { Construction of two storied laboratory at } \\
\text { Palugaswanguwa V, Siripura, Trincomalee }\end{array}$ & $3,386,800$ & 84,600 & 169,340 & 486,431 & 14.36 \\
\hline 7 & $\begin{array}{l}\text { Construction of } 25 \text { storied building with } \\
\text { Assembly Hall at Zahira MV, Trincomalee }\end{array}$ & $4,448,316$ & 112,708 & 225,416 & $1,157,640$ & 26.02 \\
\hline 8 & $\begin{array}{l}\text { Construction of three storied building with } \\
\text { Assembly Hall at Cecilia Girls School, } \\
\text { Batticaloa }\end{array}$ & $5,170,535$ & 129,200 & 258,527 & 533,047 & 10.31 \\
\hline 9 & $\begin{array}{l}\text { Construction of Assembly Hall at } \\
\text { Chenkalady MV, Batticaloa }\end{array}$ & $4,766,070$ & 119,152 & 238,304 & $1,426,865$ & 29.94 \\
\hline 10 & $\begin{array}{l}\text { Construction of Auditorium at Orr's Hill, } \\
\text { Vivekananda College, Trincomalee }\end{array}$ & $8,975,745$ & 224,394 & 448,787 & 555,788 & 6.19 \\
\hline 11 & $\begin{array}{l}\text { Construction of four storied Female } \\
\text { Dormitory for NEPC, Trincomalee }\end{array}$ & $\begin{array}{l}16,337,12 \\
8\end{array}$ & 816,900 & 816,900 & $1,708,971$ & 10.46 \\
\hline 12 & $\begin{array}{l}\text { Construction of two storied MOs quarters at } \\
\text { Base Hospital, Kalmunai South }\end{array}$ & $6,015,586$ & 300,700 & 300,700 & 568,196 & 9.45 \\
\hline 13 & $\begin{array}{l}\text { Construction of two storied MOs quarters at } \\
\text { Base Hospital, Kalmunai }\end{array}$ & $5,548,134$ & 277,400 & 277,400 & 433,550 & 7.81 \\
\hline 14 & $\begin{array}{l}\text { Construction of MOs quarters at District } \\
\text { Hospital, Addalaichenai }\end{array}$ & $1,550,000$ & 77,500 & 77,500 & 126,001 & 8.13 \\
\hline 15 & $\begin{array}{l}\text { Construction of two storied Administration } \\
\text { Block at District Hospital, Kattankudy }\end{array}$ & $4,833,899$ & 241,700 & 241,700 & 105,784 & 2.19 \\
\hline 16 & $\begin{array}{l}\text { Laying of Distribution Main-Extension to } \\
\text { China Bay }\end{array}$ & $5,245,768$ & 262,288 & 262,288 & 263,544 & 5.02 \\
\hline 17 & $\begin{array}{l}\text { Laying of distribution main-extension to } \\
\text { Thampalagama }\end{array}$ & $3,863,259$ & 193,163 & 193,163 & 225,834 & 5.85 \\
\hline 18 & Construction of Area office at Mannar & $3,596,752$ & 180,000 & 180,000 & 412,824 & 11.48 \\
\hline 19 & $\begin{array}{l}\text { Laying of Distribution Main-Extension to } \\
\text { Orr's Hill, Trincomalee }\end{array}$ & $2,632,398$ & 131,620 & 131,620 & 39,530 & 1.50 \\
\hline 20 & $\begin{array}{l}\text { Laying of Distribution Main, Trincomalee } \\
\text { WSS-Extension to Kinniya }\end{array}$ & $5,371,792$ & 268,590 & 269,590 & 175,480 & 3.27 \\
\hline 21 & Construction of Public Library at Kinniya & $3,588,987$ & 179,450 & 179,450 & 379,157 & 10.56 \\
\hline 22 & $\begin{array}{l}\text { Construction of Water Tower, Clear Water } \\
\text { tank and Pump House at Orr's Hill, } \\
\text { Trincomalee }\end{array}$ & $6,991,457$ & 393,269 & 393,269 & 500,444 & 7.16 \\
\hline 23 & $\begin{array}{l}\text { Renovation of OPD block (Ground Floor) at } \\
\text { Ampara Base Hospital }\end{array}$ & 972,766 & 48,700 & 48,700 & 68,689 & 7.06 \\
\hline 24 & $\begin{array}{l}\text { Construction of Reception Hall, Stage } 3 \text { at } \\
\text { Ninthavoor }\end{array}$ & $1,201,173$ & 60,000 & 60,000 & 59,765 & 4.98 \\
\hline 25 & $\begin{array}{l}\text { Repairs to Surgical Ward and Ward No.4 at } \\
\text { Ampara Base Hospital }\end{array}$ & 829,015 & 41,000 & 41,000 & 55,862 & 6.74 \\
\hline
\end{tabular}

Table: 1: Information about projects 
contractors. The levy charged to recover risks ranges from 1.5 to 4.5 percent of the penal sum. The contractor seeking guarantees have to furnish an irrevocable letter attested by a Notary Public directing the client to deposit all monies, including the mobilisations monies to a special project account (Lien Account) with a recognised commercial bank.

7) The responses received from the clients at the interviews regarding the problems that they encounter in forfeiting the performance bond, revealed the following:

a) The insurance companies too issue 'on demand' performance bonds similar to those issued by banks. However, unlike in banks there is a tendency for insurance companies not to honor the bond when they are called by the client. Further, it requires a lot of correspondence and persuasion before the penal sum could be released.

b) On several occasions, the clients had to go for arbitration against both the contractor and the bond provider to get the penal sum released to the client. They have had bad experience with the arbitration procedure. This is due to the overly long time it takes to reach a verdict and the costs incurred by way of legal fees for counsels and fees for other staff involved.

8) It is necessary to construct a confidence interval for the population mean of the 'total loss to the client as a percentage of the contract sum'. It was assumed that this variable has a normal distribution. It is desirable to use student ' $t$ ' distribution to construct confidence intervals on the mean of a normal random variable when the population variance is unknown regardless of the size of the sample.

The (1- a) $100 \%$ confidence interval for $\mu$ when $\sigma$ is not known (assuming normally distributed population) is $\bar{X} \pm t_{\alpha / 2} \frac{s}{\sqrt{n}}$ where $t_{\alpha / 2}$ is the value of the $t$ distribution with $(n-1)$ degrees of freedom that cuts off a tail area of $a / 2$ to its right,
$\bar{X}$ is the sample mean and ' $s$ ' is the sample standard deviation.

(Aczel and Sounderpandian, 2006)

In this sample of 25 projects,

Sample mean $=9.32$

Standard deviation $=7.241$

Sample size $=25$

Degrees of freedom $=n-1=24$.

The confidence intervals on population mean of 'total loss to the client as a percentage of the contract sum' can be constructed for different confidence levels. This can be depicted in Table 2 .

Table 2: Confidence Interval for Population mean

\begin{tabular}{|l|l|l|}
\hline$(1-\alpha) 100$ & $\alpha / 2$ & Confidence Interval \\
\hline 99 & 0.005 & $9.332 \pm 2.797=5.281,13.382$ \\
\hline 98 & 0.010 & $9.332 \pm 2.492=5.723,12.940$ \\
\hline 95 & 0.025 & $9.332 \pm 2.064=6.342,12.320$ \\
\hline 90 & 0.050 & $9.332 \pm 1.711=6.854,11.809$ \\
\hline 80 & 0.100 & $9.332 \pm 1.318=7.423,11.240$ \\
\hline
\end{tabular}

According to Table 2, the 95 percent confidence interval is [6.342, 12.320]. This can be interpreted as 95 percent confidence for the population mean of 'total loss to the client as a percentage of the contract sum' being somewhere between 6.342 and 12.320 .

\section{Discussion}

\subsection{Acceptance of performance bonds with penal sums lower than the stipulated amount}

In the analysis, it was revealed that in eight projects the penal sum of the bond is even less than five percent, in fact it is around two and half percent. In response to the query made on this, the clients admitted that they have mistakenly accepted the performance bonds which carried a penal sum of two and half percent.

\subsection{An acceptable penal sum for the performance bond}

According to the results depicted in Table 2, the population mean of 'total loss to the client as a percentage of the contract sum' is more than 6.342 percent when the level of 
confidence is 95 percent. It is necessary to find the number of projects for which the total loss to the client as a percentage of the contract sum' exceeds a given penal sum for a series of values of penal sums. Table 3 depicts the projects for which 'total loss to the client as a percentage of the contract sum' exceeds the penal sum of respective performance bonds, as a number and as well as a percentage.

Table 3: Projects of which 'total loss to the client as a percentage of the contract sum' is greater than penal sum

\begin{tabular}{|c|c|c|}
\hline $\begin{array}{c}\text { Penal sum of the } \\
\begin{array}{c}\text { Performance Bond as a } \\
\text { percentage }\end{array}\end{array}$ & $\begin{array}{l}\text { No of projects in which total } \\
\text { loss to the client }>\text { Penal sum } \\
\text { of the Performance Bond }\end{array}$ & $\begin{array}{l}\text { Projects in which total loss to the } \\
\text { client > Penal sum of the } \\
\text { Performance Bond, as a percentage }\end{array}$ \\
\hline 2.5 & 21 & 84 \\
\hline 5.0 & 19 & 76 \\
\hline 6.0 & 17 & 68 \\
\hline 6.342 & 15 & 60 \\
\hline 7.0 & 15 & 60 \\
\hline 7.5 & 14 & 56 \\
\hline 8.0 & 11 & 44 \\
\hline 9.0 & 10 & 40 \\
\hline 10.0 & 9 & 36 \\
\hline 11.0 & 6 & 24 \\
\hline 12.0 & 5 & 20 \\
\hline 12.320 & 5 & 12 \\
\hline 15.0 & 3 & 20 \\
\hline
\end{tabular}

According to Table 3, being complacent with the performance bond for which the penal sum is two and half percent is highly disadvantageous to the client; in 84 percent of the projects the total loss cannot be recovered by calling the performance bond. Even when the ICTAD recommended penal sum of five percent is exercised, the percentage of projects of which the penal sum of the performance bond is inadequate to recover the client's losses, is quite high (76 percent). Table 3 also shows the number of projects for which the 'total loss to the client as a percentage of the contract sum' exceed the penal sum when the penal sum is 6.342. However, according to the statistical analysis in Section 4, it is reasonable to assume that the probability of 'total loss to the client as a percentage of the contract sum' is between 6.342 and 12.320 is 95 percent. Therefore, it is recommended that the penal sum of the performance bond should be maintained at 12 percent to provide a greater safety margin to the client. According to the values depicted in Table 3, when the penal sum of the performance bond is 12.320 the clients are not able to recover the losses only in 20 percent of the projects.

\subsection{Feasibility of implementing the penal sum proposed for the performance bond}

According to the responses of the clients received at the interviews, the penal sum of the performance should be increased to 10 percent as it had prevailed until 1997 in order to recover the losses from defaulting contractors. Also by having a higher penal sum, the contractors will be compelled to complete the projects on time whereby avoid having to pay the penal sum. Nevertheless, on enquiry from the contractors, they were of the opinion that the existing penal sum of five percent of contract sum should not be increased any further. This is because they are already encountering great difficulty to procure performance bonds now. Hence, if the penal sum increases further, it will cause financial hardships to the contractor. Further, the contractors conveyed that, in a contract, performance bond is released only after the project is over and taking over certificate is issued. Therefore, the fund that has been dedicated to be used as collaterals to procure the performance bond will continue to be locked up. Hence, if the penal sum is 
increased, the amount of money locked with the contract will also increase. The contractors also stated that five percent of contract sum is retained with the client as retention money until the maintenance period is over. Therefore, the contractors oppose vehemently to any move to increase the penal sum beyond five percent.

There is also another consideration which needs to be analyzed before resorting to any increase in the penal sum of the performance bond. Any increase in the penal sum means implications for the cost structure of the contractor and such increase in cost will be reflected in the BOQ. This is because the contractor will pass on the costs to be incurred in obtaining the Performance Bond by loading it onto other items. This shows that any move to increase the penal sum will have a cost implication for the client.

\subsection{Problems in issuing performance bonds by Insurance companies}

In the 16 projects reviewed for the study, the bond providers are insurance companies. Predominantly, why contractors have opted to obtain bonds from insurance companies is because they do not ask for any collateral. Although, the performance bonds that insurance companies provide are 'on demand' too, the clients have to encounter greater difficulty in forfeiting the performance bond. As result, some clients now have ceased to accept performance bonds issued by the insurance companies. Also on the part of the insurers who own larger market share have stopped issuing performance bonds to contractors. However, the smaller players in the insurance industry continue to issue performance bonds under stringent conditions. The clients also pointed out that when the performance bonds are not honoured by the insurance companies, they have to resort to arbitration which is usually a time dragging and costly procedure.

\subsection{Usefulness of Construction Guarantee Fund (CGF)}

The CGF provides a guarantee to a contractor after a comprehensive assessment. This is done using the documentary evidence of his past records and bank references of the contractor's ability to perform the project. They provide guarantees without requiring the contractor to submit any form of collaterals or cash margins. Hence, the contractor has to agree to a list of requirements and conditions imposed by the CGF. In spite of the resultant tedious procedure, CGF guarantees are quite popular among the medium and small scale contractors. This is evidenced from the fact that it has issued 6078 bonds where the total penal sum is Rs. 6.0 billion and the total contract value is approximately Rs. 83.0 billion, by the year 2007.. The large scale contractors who do not want any interference of CGF in the management and financial control of their projects opt to procure guarantees from commercial banks.

\section{Conclusions and Recommendations}

1) The Client's engineer should pay particular attention to ensure that the contractor has submitted a performance bond which meets the stipulated requirements as to if it is 'on demand' and if the stipulated penal sum is correct.

2) The findings suggest that the penal sum needs to be increased to a value as high as 12 percent to ensure that clients are always safe when contractors concerns are not a consideration. In the construction industries of US and UK the penal sums of performance bonds are always greater than 10 percent. However, since the contractors' concerns regarding the increasing the penal sum is equally important, it can be concluded that the value of penal sum should be kept at a lower level than 10 percent. If a penal sum of 7.5 of the contract sum is considered, according to the Table 3, the probability of client not being able to recover losses is 56 percent; client being able to recover losses is 44 percent. Hence, the results indicate that if the penal sum can be increased up to 7.5 percent it would be an attractive compromise for both the contractor and the client alike, provided that a conducive environment is created for contractors to procure guarantees without having to go through the stringent requirements of the bond providers. 
3) In practice, it is seldom observed that performance bonds are called. If such a situation is looming there is a tendency for the contractor to negotiate with the client in an effort to get extension of time or seek permission to get the services of an alternative contractor under the same contract in order to protect his credibility in the industry. On the other hand, the clients also tend to compromise and cooperate with the contractor to complete the project whereby avoiding having to call for bonds. According to CGF, up to mid 2007 only claims up to 0.09 percent of the total value of bonds issued, has been made (CGF, 2009). In the light of the lower probability of a performance bond being claimed, it is recommended that the penal sum of performance bond should remain at five percent even though it is inadequate to recover client's losses in a contract in which the contractor has defaulted. When the penal sum is capped at five percent the client is at a loss in the event of performance bond being invoked. However, the probability of its occurrence is marginal.

4) The clients have a tendency to specify the type of performance bond that they would accept from the three types mentioned earlier. However, as of late most clients do not accept insurance bonds. Hence, clients should be made to understand the prevailing situation and persuaded to accept insurance bonds. Also the insurance bonds should be made more stringent making the insurance companies legally bound to honour the bonds. The insurance companies can in turn increase their commissions further so that their liabilities are adequately covered. It was observed in situations where the clients are willing to accept the insurance bonds, this is their first preference since it does not necessitate them to keep deposits as collaterals. The bank guarantees are always acceptable as performance bonds. Although the commissions charged by CGF can be slightly higher than the levies charged in other forms of guarantees the contractors prefer guarantees issued by the CGF to others.
5) The statutory bodies and professional institutes in the construction industry should take steps to educate the state sector clients, large private sector clients and policy makers through seminars, publications etc. Questions of how to mitigate the risk of contractor nonperformance when proper procedures are followed during preconstruction phase and construction phase should be addressed. This will minimize the incidence of having to call for performance bonds which will invariably make the requirements that the contractor has to fulfil in procuring a performance bond less stringent. It will also make the bond providers confident enough to charge lower levies and commissions on performance bonds.

6) As stipulated in the ICTAD conditions of contract, the contractors have to be paid within 30days from the date of receipt of an interim bill. Nonetheless, in practice, the interim bills are not settled within the stipulated period and this affects the project cash flow of the contractor. Such cash flow problems could cause delays in the project completion, in addition to incurring losses to the contractor. Hence, if measures could be taken to ensure that interim bills are settled within the stipulated period, the necessity to amend the penal sum may not arise.

7) It is a genuine grievance of contractors that the contract documents pertaining to the project contain flaws owing to the negligence and the incompetence of the appointed consultants. Usually, the time taken to receive a correction to such flaws is unduly long. Further, the time taken to receive a clarification regarding technical or contractual matters could be longer which invariably contributes to delays. However, the client is not held accountable for these delays although his part is clearly contributory. Therefore, the onus of engaging competent consultants and of providing accurate contract documents should essentially be on the client and this should be contractually agreed. This is a viable preventive measure to minimise potential delays. 


\section{References}

1. Bennet, H.N. (1994), Performance bonds and the principal of autonomy, Journal of Business Law, pp.574-586.

2. Contract Journal.com, Performance bonds- Legal(Spiersbridge Property Developments Limited v- Muir Construction Limited), 4/2/2008, <http://www.contractjournal.com/Articles / 20 08/04/02/58392/performance-bondsspiersbridge-property-developments-v-muirconstruction.html.

3. Construction Guarantee (2008) Performance Bonds in Construction, Information for Contractors and sub- contractors, Montrose, Dublin 4, <http://www.constructionguarantee. ie/en/homepage.aspx.

4. Construction Guarantee Fund (CGF), (2009), Information brochures, Sri Lanka.

5. Dingman, M.S. (2000) How the owner derives benefits from a performance bonds, Readsmith publications

6. Donohue and Thomas (1996) Construction Surety Bonds In Plain English, Construction Briefings, Federal Publications, Incorporated, 1120 20th Street, N.W., Washington, D.C. 20036.

7. Engineering News Record (2004), Delayed Firm Can't Collect On Project Performance Bond, Engineering News Record, 7/12/2004 Vo. 253, Issue 2.

8. Ndekugri, I. (1999), Performance bonds and Guarantees: Construction Owners and professionals beware, Journal of Construction Engineering and management, Vol.125, No.6, November, pp.428-435.

9. Rossesetti, K. and McKeeman, M.T. (2007) Termination Notification Short Circuits Electrical Subcontract's Performance Bonds, Cost Engineering Vol. 49/No.9, September, pp.8-9. 